\title{
DEVELOPMENT AND PRODUCTION OF FERTIGATED COFFEE TREES IN THE WEST REGION OF BAHIA, BRAZIL
}

\author{
Marcelo Rossi Vicente ${ }^{1}$, Everardo Chartuni Mantovani², André Luís Teixeira Fernandes ${ }^{3}$, \\ Julio Cesar Lima Neves ${ }^{4}$, Santos Henrique Brant Dias ${ }^{5}$, Edmilson Marques Figueredo ${ }^{6}$
}

(Received: January 24, 2017; accepted: Monday, May 8, 2017)

\begin{abstract}
The aim in the present study was to evaluate the effects of different split fertigation and doses on the development and production of drip irrigated coffee in the western region of the state of Bahia, Brazil. The study was performed at the Café do Rio Branco Farm, in Barreiras, BA, Brazil, in adult coffee trees aged approximately 3.5 years from the variety Catuai IAC 144. A 3 x 3 factorial design was adopted, with three levels of nitrogen and potassium fertilization (900/800, 600/500 and 300/250 kg ha-1 year ${ }^{-1} \mathrm{~N}$ and $\mathrm{K}_{2} \mathrm{O}$ ) in three monthly split fertigation (two, four and eight times). Stem and crown growth, productivity, yield and sieve were evaluated. The doses of $600 / 500$ and $900 / 800 \mathrm{~kg} \mathrm{ha}^{-1}$ year ${ }^{-1} \mathrm{~N} / \mathrm{K}_{2} \mathrm{O}$ and the splits in two and eight times provided the highest productivities of coffee. A higher split fertigation was observed on the effect of $\mathrm{N}_{\text {and }} \mathrm{K}_{2} \mathrm{O}$ doses in coffee development variables (crown diameter and plant height). There was no effect of split fertigation and doses in the classification by sieves of coffee beans.
\end{abstract}

Index terms: Coffea arabica L., irrigation, nitrogen, potassium.

\section{DESENVOLVIMENTO E PRODUÇÃO DO CAFEEIRO FERTIRRIGADO NA REGIÃO OESTE DA BAHIA}

RESUMO: Este trabalho foi realizado com o objetivo de avaliar os efeitos de diferentes doses e parcelamentos da fertirrigação no desenvolvimento e na produção do cafeeiro irrigado por gotejamento na região Oeste da Bahia. O trabalho foi conduzido na fazenda Café do Rio Branco, localizada em Barreiras - BA, em cafeeiros adultos, com aproximadamente 3,5 anos de idade, da variedade Catuaí IAC 144. Foi adotado um esquema fatorial 3 x 3, sendo três níveis de adubação nitrogenada e potássica (900/800, 600/500 e 300/250 kg ha-1 ano-1 de N e K2O) em 3 parcelamentos mensais de fertirrigação (2, 4 e 8 vezes). Foram avaliados o crescimento do caule e copa, a produtividade, o rendimento e peneira. As doses de 600/500 e 900/800 kg ha- 1 ano- 1 de N/K2O e os parcelamentos em dois e oito vezes proporcionaram as maiores produtividades do cafeeiro. Observou-se efeito maior do parcelamento da fertirrigação, sobre o efeito das doses de $\mathrm{N}$ e $\mathrm{K} 2 \mathrm{O}$, nas variáveis de desenvolvimento do cafeeiro (diâmetro de copa e altura de planta). Não houve efeito das doses e parcelamento da fertirrigação na classificação por peneira dos grãos do café.

Termos para indexação: Coffea arabica L., irrigação, nitrogênio, potássio.

\section{INTRODUCTION}

Irrigation is characterized as part of a set of techniques used to guarantee the economic production of coffee, with adequate management of natural resources (MANTOVANI; VICENTE, 2015).

The water requirement of the coffee tree is a limiting factor in bean yield and quality, being the minimum limit required by the coffee tree during a cycle is $800 \mathrm{~mm}$ (VENANCIO et al., 2016). Associated with water consumption is the phenomenon of mass flow, responsible for large part of plant's absorption of nutrients. Based on this, research correlating the supply of water and fertilizer arose from the fertigation. Currently, fertigation has been intensively used in coffee growing through irrigation systems that apply water and conventional fertilizers, saving labor force and with better fertilizer distribution in the area.

The benefits of the fertigation technique are limited due to the scarcity of specific scientific information for the coffee tree, especially in relation to the doses and split number required in the year (SOBREIRA et al., 2011).

Fernandes et al. (2007) evaluated coffee fertigation in Uberaba, MG, Brazil, after four harvests and observed that the used fertilizer sources both in fertigation and in conventional soil application did not show significant differences in terms of coffee productivity and quality.

${ }^{1}$ Federal Institute of Education, Science and Technology of the North of Minas Gerais - Campus Salinas - Faz. Varginha, Km 02 Rod. Salinas/Taiobeiras - 39.560-000 - Salinas - MG - marcelo.vicente@ifnmg.edu.br

2,4,5 Federal University of Viçosa - Av. PH Rolfs, S/N - 36.571-000 - Viçosa - MG - everardo@ufv.br, julio_n2003@yahoo.com.br, santosdiasagro@gmail.com

${ }^{3}$ University of Uberaba - Av. Nenê Sabino, n 1801-38.055-500 - Uberaba - MG - andre.fernandes@uniube.br

${ }^{6}$ Bahia Farm Show - Av. Ahylon Macedo, n 919 - 97.810-035 - Barreiras - BA - edmilson@bahiafarmshow.com.br 
Lima et al. (2016), in Araguari, MG, Brazil, evaluated the vegetative and productive parameters of coffee as a function of different sources, doses and forms of nitrogen application and observed that agricultural urea applied through fertigation was not better in the vegetative and productive parameters of the coffee tree in relation to the applied conventionally, and that the conventionally applied ammonium nitrate can be considered as the best source of $\mathrm{N}$ when all the variables are analyzed together.

Coelho et al. (2009), in an experiment performed in Lavras, MG, Brazil, did not observe an effect of the split number of N, P and K $(4,12$, 24 and 36 applications) applied through fertigation in the coffee productivity.

Although there are publications on the application of fertilizers through irrigation water, it is verified that there is still a need for research on fertilizer doses for the coffee tree, since there are several variables involved in the use of this technique.

The aim in the present study was to evaluate the effects of different doses and split fertigation by dripping on production and development of coffee tree in western Bahia region, Brazil.

\section{MATERIAL AND METHODS}

The experiment was installed in adult coffee plantations, aged approximately 3.5 years, Catuai Vermelho IAC 144 variety, spaced 3.80 x $0.5 \mathrm{~m}$ with drip irrigation at Fazenda Café do

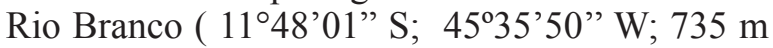
altitude) municipality of Barreiras, BA, Brazil. The analyzed period was from November 2004 to May 2008.

Soil texture analysis is presented in Table 1. Field capacity value was determined from the 5 $\mathrm{kPa}$ tension as a function of the soil texture in the experiment. For the permanent wilting point, the moisture corresponding to the $1540 \mathrm{kPa}$ tension was adopted. Soil moisture values corresponds to the field capacity and permanent wilting point, in the $0-60 \mathrm{~cm}$ profile, were 27.01 and $17.63 \%$ volume, respectively.

Urea was used as source of nitrogen and potassium chloride with potassium source.

The crop evapotranspiration (ETc) was estimated using the coefficients of adjustment ("kc" crop, "kl" landscape and "ks" soil) on reference evapotranspiration (ETo), according to the methodologies described by Mantovani et al. (2009) and Mantovani and Vicente (2015). The gross irrigation depth was calculated through a water balance using the Irriplus software (MANTOVANI et al., 2009), in which the inputs of water were the irrigation and the effective rainfall, and the outputs, crop evapotranspiration (ETc) and percolation depth, besides the depth considered for the root system.

The method for estimating the ETo used by Irriplus is the Penman-Monteith-FAO 56 model (ALLEN et al., 1998; PEREIRA et al., 2015). The meteorological data used to perform the experiment were obtained from an automatic agrometeorological station, Davis brand, Vantage Pro model, located on the property.

In the experiment, the values of the crop coefficient $(\mathrm{Kc})$, percentage of shaded area $(\mathrm{P})$ and effective depth of the root system were 1.0, $50 \%$ and $0.60 \mathrm{~m}$, respectively, were used.

The experiment used drip irrigation, with flow emitters $2.3 \mathrm{~L} \mathrm{~h}^{-1}$, spaced every $0.75 \mathrm{~m}$.

Harvests were performed manually. Coffee production of the plot was determined after each harvest, and two $5 \mathrm{~L}$ samples were taken to determine the yield and sieve of each treatment. The productivity result was calculated in $60 \mathrm{~kg}$ bags of processed coffee per hectare (bg ha-1).

To evaluate the vegetative development, the plant height and crown and stem diameter were considered. For measuring the crown diameter, the perpendicular length to the planting line was determined as reference. The evaluations were performed on December 10, 2005 and September 19, 2007.

The development variables (plant height, crown and stem diameter), sieve classification and yield of coffee fruits were performed by analysis of variance by $\mathrm{F}$ test at $5 \%$ probability. Means were compared using the Tukey test at 5\% probability.

\section{RESULTS AND DISCUSSION}

In Figure 1 are observed the soil moisture content estimated by Irriplus, the safe soil moisture (moisture relative to the soil water availability factor), the irrigation depths and the rainfall occurred throughout the experiment during the analyzed period (November 2004 to May 2008). The total applied irrigation depth was $3,029 \mathrm{~mm}$ $(135,1083,645,919$ and $247 \mathrm{~mm}$ for the years 2004, 2005, 2006, 2007 and 2008, respectively) and accumulated rainfall was $3,715 \mathrm{~mm}$ (321, $1075,1210,588$ and $522 \mathrm{~mm}$ for the years 2004, 2005, 2006, 2007 and 2008, respectively). 
TABLE 1- Particle size composition, texture classification and soil specific weight.

\begin{tabular}{|c|c|c|c|c|c|}
\hline \multirow{2}{*}{ Depth $(\mathrm{cm})$} & \multicolumn{3}{|c|}{ Particle size composition ( $\%)$} & \multirow{2}{*}{$\begin{array}{l}\text { Soil density } \\
\qquad\left(\mathrm{g} / \mathrm{cm}^{3}\right)\end{array}$} & \multirow{2}{*}{ Texture classification } \\
\hline & Sand & Silt & Clay & & \\
\hline $0-20$ & 65.53 & 2.23 & 32.24 & 1.57 & Sandy clay loam \\
\hline $20-40$ & 63.37 & 2.86 & 33.78 & 1.57 & Sandy clay loam \\
\hline $40-60$ & 57.20 & 2.83 & 39.97 & 1.47 & Sandy clay \\
\hline
\end{tabular}

The experiment was set up in a $3 \times 3$ factorial design with three levels of nitrogen and potassium fertilization, in three split fertigation (Table 2), and the randomized block design with four replicates. The experimental plots consisted of 20 plants $(10 \mathrm{~m})$.

TABLE 2 - Description of the different treatments of $\mathrm{N}$ and $\mathrm{K}_{2} \mathrm{O}$ levels and splits, Barreiras, BA, Brazil

\begin{tabular}{|c|c|c|c|c|}
\hline \multirow{2}{*}{ Treatment } & \multicolumn{2}{|c|}{ Doses $\left(\mathrm{kg} \mathrm{ha}^{-1}\right.$ year $\left.^{-1}\right)$} & \multirow{2}{*}{ Split } & \multirow{2}{*}{ No. monthly applications } \\
\hline & $\mathrm{N}$ & $\mathrm{K}_{2} \mathrm{O}$ & & \\
\hline 1 & 900 & 800 & & 2 \\
\hline 2 & 600 & 500 & every 15 days & 2 \\
\hline 3 & 300 & 250 & & 2 \\
\hline 4 & 900 & 800 & & 4 \\
\hline 5 & 600 & 500 & 1 per week & 4 \\
\hline 6 & 300 & 250 & & 4 \\
\hline 7 & 900 & 800 & & 8 \\
\hline 8 & 600 & 500 & 2 per week & 8 \\
\hline 9 & 300 & 250 & & 8 \\
\hline
\end{tabular}

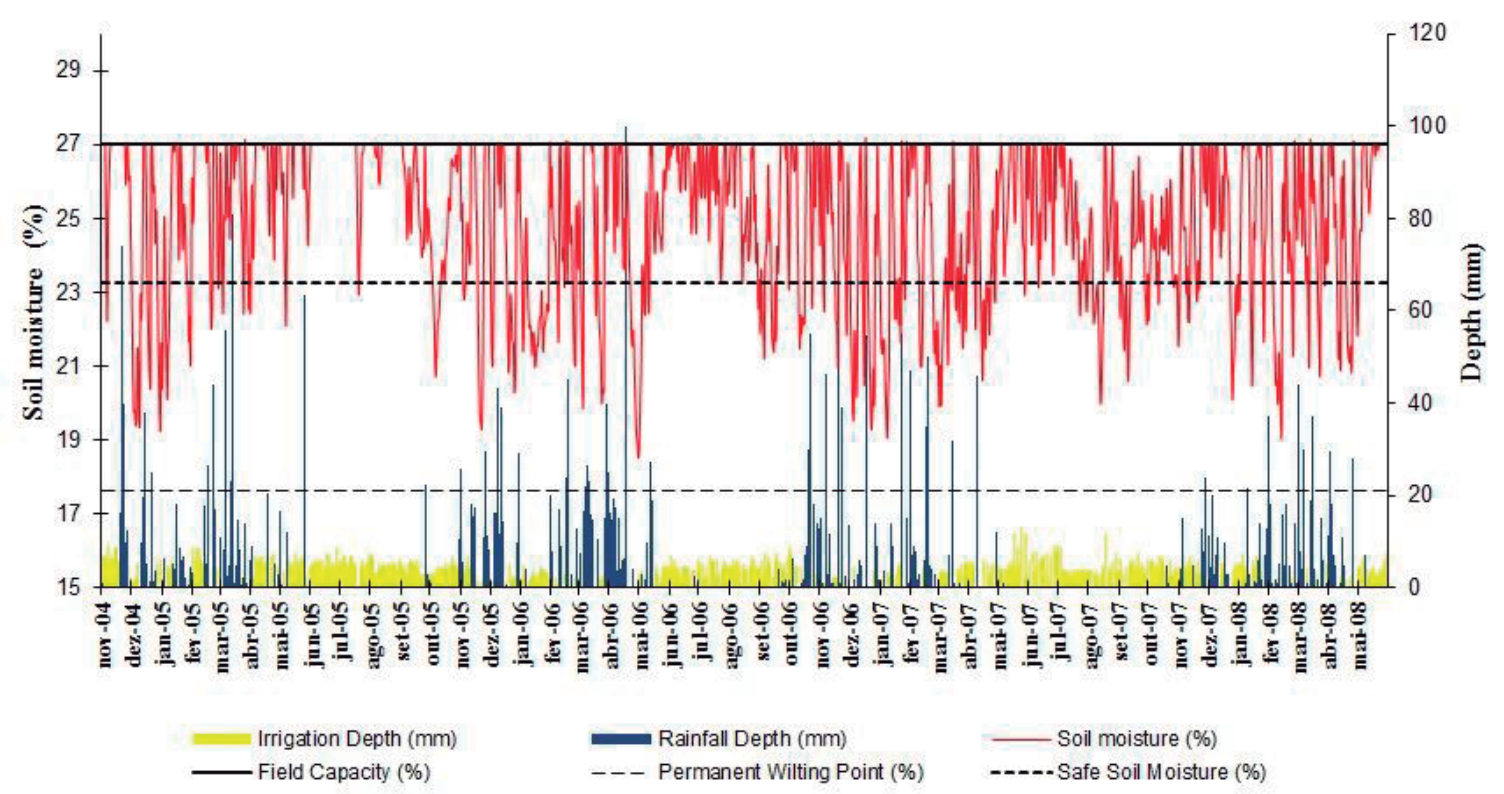

FIGURE 1 - Soil (volumetric) moisture estimated by the Irriplus software, applied irrigation depths and rainfall for the experiment.

Coffee Science, Lavras, v. 13, n. 1, p. 90 - 97, jan./mar. 2018 
There was an isolated effect among the different doses $(p<0.05)$ for coffee productivity, in bg ha ${ }^{-1}$ for the harvests 2005, 2006, 2008, and for the average of the four studied harvests (Table $3)$.

The doses $600 / 500$ and 900/800 (N/ $\left.\mathrm{K}_{2} \mathrm{O}\right)$ differed from the dose $300 / 250$ in the average of four harvests, being that the dose 600/500 provided the highest average productivity, occurring the same in the 2006 and 2008 harvests. The dose of $600 / 500 \mathrm{~N} / \mathrm{K}_{2} \mathrm{O}$, according to the obtained productivity $\left(60.9^{2} \mathrm{bg} \mathrm{ha}^{-1}\right)$ corroborates Santinato (2005) for the western region of Bahia, Brazil, which observed the requirements of $574 \mathrm{~kg}$ $\mathrm{ha}^{-1} \mathrm{~N}$ and $454 \mathrm{~kg} \mathrm{ha}^{-1} \mathrm{~K}_{2} \mathrm{O}$ for obtaining similar productivity. For the same region, Guerra et al. (2007) state that the doses of $500-600 \mathrm{~kg} / \mathrm{ha} \mathrm{N}$ and $\mathrm{K}_{2} \mathrm{O}$, generally applied in crops with productive potential from 60 to $70 \mathrm{bg} / \mathrm{ha}$, are consistent with the research results obtained at Embrapa Cerrados and are adequate to meet the needs of coffee trees.

The four harvest average did not present higher productivity at the 900/800 dose (Table 3) because of the nutrient leaching.In a study performed on coffee plantations in the western Bahia, Brazil, Bortolotto et al. (2012) verified that the nitrogen leaching corresponding to $104.5 \mathrm{~kg}$ $\mathrm{ha}^{-1}$ at the dose of $800 \mathrm{~kg} \mathrm{ha}^{-1} \mathrm{~N}$ applied as urea was associated with concentrated rainfall.

The found results contrast with the obtained by Rena, Nacif and Guimarães (2003) in Patrocínio, MG, Brazil. The authors observed that doses of 1000-1200 kg ha-1 year'-1 of 20-5-20 (200-240 kg ha ${ }^{-1}$ year $^{-1} \mathrm{~N}$ and $\mathrm{K}_{2} \mathrm{O}$ ) were sufficient to meet the demands of coffee, although it is worth mentioning that the productivity under dry conditions obtained by the authors was $31.0 \mathrm{bg}$ $\mathrm{ha}^{-1}$, almost half of that obtained in the present experiment.

There was also an isolated effect of the fertigation frequency $(\mathrm{P}<0.05)$ on coffee yield, in $\mathrm{bg} \mathrm{ha} \mathrm{h}^{-1}$, for all the crops except for the 2006 harvest and the average of four harvests (Table 4).

Split in two monthly applications provided higher productivity than the other splits, not statistically differing from the split fertigation applied eight times a month for the average of four harvests.

Coelho et al. (2009), in Lavras, MG, Brazil, observed that the split application of fertilizers did not result in differences on coffee productivity. Karasawa, Faria and Guimarães (2002) and Vilella and Faria (2003) in Lavras, did not observe a significant effect of split nutrient.

Sant'ana (2015) observed in Lavras that the average productivity of the 2010, 2011, 2012 and 2013 harvests were not influenced by the split nitrogen and potassium fertilization (four applications in Nov, Dec, Jan and Feb and 12 monthly applications), although observing higher leaching with lower splits. Lima et al. (2016) also did not observe effect of urea fertigation (weekly splits from September of each year until July of the following year) in relation to conventional fertilization split in three applications (November, January and March of all evaluated years).

TABLE 3 - Productivity, in bags per hectare, of fertigated coffee trees subjected to different doses of $\mathrm{N}_{\text {and }} \mathrm{K}_{2} \mathrm{O}$

\begin{tabular}{cccccc}
\hline \multirow{2}{*}{ Doses $\left(\mathrm{kg} \mathrm{ha}^{-1}\right.$ year $\left.^{-1}\right)\left(\mathrm{N} / \mathrm{K}_{2} \mathrm{O}\right)$} & \multicolumn{5}{c}{ Productivity $\left(\mathrm{bg} \mathrm{ha}^{-1}\right)$} \\
\cline { 2 - 6 } & 2005 & 2006 & 2007 & 2008 & Average \\
\hline $600 / 500$ & $52.2 \mathrm{AB}$ & $68.9 \mathrm{~A}$ & $58.9 \mathrm{~A}$ & $67.3 \mathrm{~A}$ & $60.9 \mathrm{~A}$ \\
$900 / 800$ & $53.7 \mathrm{~A}$ & $64.5 \mathrm{~A}$ & $54.9 \mathrm{~A}$ & $66.1 \mathrm{AB}$ & $60.4 \mathrm{~A}$ \\
$300 / 250$ & $49.1 \mathrm{~B}$ & $50.7 \mathrm{~B}$ & $61.3 \mathrm{~A}$ & $55.5 \mathrm{~B}$ & $53.3 \mathrm{~B}$ \\
\hline Averages followed by the same letter on the column do not differ among themselves by Tukey test $(\mathrm{p}<0.05)$
\end{tabular}

TABLE 4 - Productivity, in bags per hectare, of coffee tree subjected to different monthly split fertigation, in Barreiras, BA, Brazil

\begin{tabular}{cccccc}
\hline \multirow{2}{*}{$\begin{array}{c}\text { Split } \\
\text { (monthly) }\end{array}$} & 2005 & 2006 & 2007 & 2008 & Average \\
\cline { 2 - 6 } & $56.1 \mathrm{~A}$ & $62.6 \mathrm{~A}$ & $63.0 \mathrm{~A}$ & $62.1 \mathrm{AB}$ & $60.9 \mathrm{~A}$ \\
8 & $53.3 \mathrm{AB}$ & $61.6 \mathrm{~A}$ & $51.6 \mathrm{~B}$ & $69.3 \mathrm{~A}$ & $58.5 \mathrm{AB}$ \\
4 & $45.6 \mathrm{~B}$ & $59.9 \mathrm{~A}$ & $55.6 \mathrm{AB}$ & $57.8 \mathrm{~B}$ & $55.2 \mathrm{~B}$ \\
\hline
\end{tabular}

Averages followed by the same letter on the column do not differ among themselves by Tukey test $(\mathrm{p}<0.05)$ 
In the analyses, interaction between doses and monthly split fertilization was significant ( $\mathrm{P}$ $<0.05$ ) for coffee productivity in the 2005 and 2007 harvests and for the average of four harvests (Table 5).

Similar results were found by Leite Júnior and Faria (2016), obtaining a productivity average of 63.5 bags for the most productive year and 38 bags for the lowest productive year, thus concluding that fertigation make possible to stagger production and increase productivity.

Treatment $2\left(600 / 500 \mathrm{~kg} \mathrm{ha}^{-1}\right.$ year $^{-1} \mathrm{~N} /$ $\mathrm{K}_{2} \mathrm{O}$ with two monthly splits) showed the highest productivity in the average of four studied harvests $\left(65.6 \mathrm{bg} \mathrm{ha}^{-1}\right)$. Treatment $3\left(300 / 250 \mathrm{~kg} \mathrm{ha}^{-1}\right.$ year $^{-1}$ $\mathrm{N} / \mathrm{K}_{2} \mathrm{O}$ with two monthly splits) provided higher productivities in the 2005 and 2007 harvests, but lower than the treatment 2 on average. The higher productivities in the 2005 and 2007 harvests for treatment 3 can be explained by the more efficient use of nitrogen, as observed by Bruno et al. (2015), in Barreiras, MG, Brazil, where the dose of $200 \mathrm{~kg}$ $\mathrm{N}$ ha $^{-1}$ year $^{-1}$ urea showed the lowest losses and greater $\mathrm{N}$ recoveries by coffee.

In Table 4 is noted that split is more relevant in the years of low productivity (2005 and 2007) and the dose in the years of high productivity (2006 and 2008), although observing interaction between dose and split.

The results corroborate with the presented by Bruno et al. (2011), demonstrating that it is possible to reduce the nitrogen dose from $600 \mathrm{~kg}$ $\mathrm{ha}^{-1}$ year ${ }^{-1}$ to $200 \mathrm{~kg} \mathrm{ha}^{-1}$ without decreasing coffee yield. It should be highlighted that the authors evaluated only one harvest, i.e., the effect on future harvests were not evaluated.

For the analyses of coffee development (crown diameter and stem height), a statistical difference $(p<0.05)$ was observed in the first evaluation between the doses and splits for the crown diameter and between the splits and stem height.

TABLE 5 - Productivity, in bags per hectare, of coffee tree subjected to different monthly doses and split fertigation

\begin{tabular}{|c|c|c|c|}
\hline \multirow{3}{*}{ Doses $\left(\mathrm{kg} \mathrm{ha}^{-1}\right.$ year $\left.^{-1}\right)\left(\mathrm{N} / \mathrm{K}_{2} \mathrm{O}\right)$} & \multicolumn{3}{|c|}{ Monthly split } \\
\hline & 2 & 4 & 8 \\
\hline & \multicolumn{3}{|c|}{ Productivity $2005\left(\right.$ bg ha $\left.^{-1}\right)$} \\
\hline $900 / 800$ & $50.0 \mathrm{~A} \mathrm{a}$ & $51.2 \mathrm{~A} \mathrm{a}$ & $59.8 \mathrm{~A} \mathrm{a}$ \\
\hline $600 / 500$ & $54.8 \mathrm{AB}$ a & $42.4 \mathrm{~B} \mathrm{a}$ & $59.4 \mathrm{~A} \mathrm{a}$ \\
\hline \multirow[t]{2}{*}{$300 / 250$} & $63.3 \mathrm{~A} \mathrm{a}$ & $43.2 \mathrm{~B} \mathrm{a}$ & $40.9 \mathrm{~B} \mathrm{~b}$ \\
\hline & \multicolumn{3}{|c|}{ Productivity $2006\left(\right.$ bg ha $\left.^{-1}\right)$} \\
\hline $900 / 800$ & $67.4 \mathrm{~A} \mathrm{a}$ & $67.1 \mathrm{~A} \mathrm{a}$ & $59.1 \mathrm{~A} \mathrm{a}$ \\
\hline $600 / 500$ & $77.1 \mathrm{~A} \mathrm{a}$ & $64.2 \mathrm{~A} \mathrm{a}$ & $65.5 \mathrm{~A} \mathrm{a}$ \\
\hline \multirow[t]{2}{*}{$300 / 250$} & $43.3 \mathrm{~A} \mathrm{a}$ & $53.5 \mathrm{~A} \mathrm{a}$ & $55.2 \mathrm{~A} \mathrm{a}$ \\
\hline & \multicolumn{3}{|c|}{ Productivity $2007\left(\right.$ bg ha $\left.^{-1}\right)$} \\
\hline $900 / 800$ & $50.5 \mathrm{Ab}$ & $64.8 \mathrm{~A} \mathrm{a}$ & $56.3 \mathrm{~A} \mathrm{a}$ \\
\hline $600 / 500$ & $61.3 \mathrm{Ab}$ & $55.8 \mathrm{~A} \mathrm{ab}$ & $47.7 \mathrm{~A} \mathrm{a}$ \\
\hline \multirow[t]{2}{*}{$300 / 250$} & $77.1 \mathrm{~A} \mathrm{a}$ & $46.3 \mathrm{~B} \mathrm{~b}$ & $50.87 \mathrm{a}$ \\
\hline & \multicolumn{3}{|c|}{ Productivity $2008\left(\right.$ bg ha $\left.^{-1}\right)$} \\
\hline $900 / 800$ & $67.0 \mathrm{~A} \mathrm{a}$ & $61.0 \mathrm{~A} \mathrm{a}$ & $70.4 \mathrm{~A} \mathrm{a}$ \\
\hline $600 / 500$ & $69.2 \mathrm{~A} \mathrm{a}$ & $60.5 \mathrm{~A} \mathrm{a}$ & $79.0 \mathrm{~A} \mathrm{a}$ \\
\hline \multirow[t]{2}{*}{$300 / 250$} & $50.0 \mathrm{~A} \mathrm{a}$ & $52.0 \mathrm{~A} \mathrm{a}$ & $64.5 \mathrm{~A} \mathrm{a}$ \\
\hline & \multicolumn{3}{|c|}{ Average productivity $\left(\mathrm{bg} \mathrm{ha}^{-1}\right)$} \\
\hline $900 / 800$ & $58.7 \mathrm{Ab}$ & $61.0 \mathrm{~A} \mathrm{a}$ & $61.4 \mathrm{~A} \mathrm{a}$ \\
\hline $600 / 500$ & $65.6 \mathrm{~A} \mathrm{a}$ & $55.8 \mathrm{~B} \mathrm{a}$ & $61.4 \mathrm{AB}$ a \\
\hline $300 / 250$ & $58.4 \mathrm{~A} \mathrm{~b}$ & $48.8 \mathrm{~B} \mathrm{~b}$ & $52.9 \mathrm{AB} \mathrm{b}$ \\
\hline
\end{tabular}

Averages followed by the same capital letter on the row and same lowercase letter on the column within each harvest do not differ among themselves by Tukey test $(\mathrm{P}<0.05)$ 
In the second evaluation, a statistical difference $(\mathrm{p}<0.05)$ was verified between the doses only for the crown diameter. In Tables 6 , 7 and 8 are presented the results of the first and second biometric measurements of the experiment.

It is observed in Table 6 that the 600/500 dose of $\mathrm{N}$ and $\mathrm{K}_{2} \mathrm{O}$ provided the largest crown diameter in the first evaluation, while the best result was observed at the 300/250 dose in the second evaluation. The results are similar to the found by Nazareno et al. (2003) and Rezende et al. (2010), which observed a response to $\mathrm{N}$ and $\mathrm{K}$ for crown diameter and growth in number of plagiotropic branches, demonstrating the synergistic effect of adequate water availability and better nutrient distribution in fertilizers, concluding that fertigation is a good alternative to be used in the formation of coffee plants to the detriment of conventional fertilization.
In the first evaluation, the largest crown diameter of coffee tree was provided by split fertigation eight times per month (Table 7), differing only from the splits applied four times. The small difference between the average crown diameter for the first and second crop (191.9 and $189.0 \mathrm{~cm}$, respectively) may be correlated with the fact that the first evaluation was performed in the rainy season in contrast to the second one at the end of the dry period of the year.

For stem development (Table 8), it is noted that split fertigation applied eight times provided the highest average stem growth $(67.2 \mathrm{~cm})$ in 21 months.

The effect of the monthly split on the yield, in liters of coffee per acre $(\mathrm{p}<0.05)$, was observed in the 2008 harvest (Table 9).

TABLE 6 - Average crown diameter of coffee in centimeters as a function of the different doses of $\mathrm{N}_{\text {and }} \mathrm{K}_{2} \mathrm{O}$ in the two evaluations

\begin{tabular}{ccc}
\hline Doses $\left(\mathrm{kg} \mathrm{ha}^{-1}\right.$ year $\left.^{-1}\right)$ & \multicolumn{2}{c}{ Crown diameter $(\mathrm{cm})$} \\
\cline { 2 - 3 } $\mathrm{N} / \mathrm{K}_{2} \mathrm{O}$ & 1st evaluation & 2nd evaluation \\
\hline $900 / 800$ & $191.4 \mathrm{AB}$ & $185.7 \mathrm{~B}$ \\
$600 / 500$ & $197.2 \mathrm{~A}$ & $188.6 \mathrm{AB}$ \\
$300 / 250$ & $187.2 \mathrm{~B}$ & $192.5 \mathrm{~A}$ \\
\hline Averages followed
\end{tabular}

Averages followed by the same letter on the column do not differ among themselves by Tukey test $(\mathrm{p}<0.05)$

TABLE 7 - Crown diameter of coffee in centimeters as a function of the different monthly splits of $\mathrm{N}_{\text {and }} \mathrm{K}_{2} \mathrm{O}$ in the two evaluations

\begin{tabular}{ccc}
\hline Split & \multicolumn{2}{c}{ Crown diameter $(\mathrm{cm})$} \\
\cline { 2 - 3 } (monthly) & $12 / 10 / 2005$ & $9 / 19 / 2007$ \\
\hline 2 & $191.5 \mathrm{AB}$ & $186.9 \mathrm{~A}$ \\
4 & $186.8 \mathrm{~B}$ & $188.6 \mathrm{~A}$ \\
8 & $197.4 \mathrm{~A}$ & $191.3 \mathrm{~A}$ \\
\hline
\end{tabular}

Averages followed by the same letter on the column do not differ among themselves by Tukey test $(\mathrm{p}<0.05)$

TABLE 8 - Stem height of coffee in centimeters as a function of the different monthly splits of $\mathrm{N}_{\text {and }} \mathrm{K}_{2} \mathrm{O}$ in the two evaluations

\begin{tabular}{ccc}
\hline \multirow{2}{*}{$\begin{array}{c}\text { Split } \\
\text { (monthly) }\end{array}$} & \multicolumn{2}{c}{ Stem height $(\mathrm{cm})$} \\
\cline { 2 - 3 } 2 & $12 / 10 / 2005$ & $9 / 19 / 2007$ \\
\hline 4 & $213.0 \mathrm{~A}$ & $266.0 \mathrm{~A}$ \\
8 & $209.4 \mathrm{AB}$ & $267.1 \mathrm{~A}$ \\
& $203.3 \mathrm{~B}$ & $270.5 \mathrm{~A}$
\end{tabular}

Averages followed by the same letter on the column do not differ among themselves by Tukey test $(\mathrm{p}<0.05)$ 
TABLE 9 - Yield $\left(\mathrm{L} \mathrm{bg}^{-1}\right)$ of coffee necessary to produce one processed bag

\begin{tabular}{cc}
\hline $\begin{array}{c}\text { Split } \\
\text { (monthly) }\end{array}$ & $\begin{array}{c}\text { Yield } \\
\text { (liters of coffee per processed bag) }\end{array}$ \\
\hline 4 & $531 \mathrm{~A}$ \\
2 & $518 \mathrm{AB}$ \\
8 & $512 \mathrm{~B}$ \\
\hline
\end{tabular}

Averages followed by the same letter do not differ among themselves by Tukey test $(\mathrm{p}<0.05)$

The split four times a month provided the best yield. It can be observed in Table 4, for the 2008 harvest, that the split four times per month also provided the lowest productivity in relation to the other splits. The yield is affected considerably by water deficit occurring in the expansion of the coffee bean (October-December), which did not occur throughout the experiment. Such difference in the yield can be explained by the greater easiness in filling the coffee bean by the treatments subjected to the split four times a month, since were produced in smaller amount.

There were no significant effects of treatments on the percentage of beans classified in the 16-mesh sieve or above. The percentage found was $46.3 \%$, translating into a good coffee percentage for export, since exporters prefer larger beans, thus automatically eliminating defects. This value is consistent with that presented by Custódio, Gomes and Lima (2007).

\section{CONCLUSIONS}

The doses of $600 / 500$ and $900 / 800 \mathrm{~kg} \mathrm{ha}^{-1}$ year $^{-1} \mathrm{~N} / \mathrm{K}_{2} \mathrm{O}$ provided the highest productivities of coffee;

Split fertigation applied two and eight times a month was superior in productivity;

A higher split fertigation was observed on the effect of $\mathrm{N}$ and $\mathrm{K}_{2} \mathrm{O}$ doses in coffee development variables (crown diameter and plant height).

There was no effect of split fertigation and doses in the classification by sieves of coffee beans;

Split fertigation applied four times a month resulted in a better yield, in liters of coffee per acre, for the 2008 harvest, although this same split provided lower productivity than the others.

\section{REFERENCES}

ALLEN, R. G. et al. Crop evapotranspiration: guidelines for computing crop water requirements. Rome: FAO, 1998. 319 p. (Irrigation and Drainage Paper, 56).
BORTOLOTTO, R. P. et al. Nitrogen fertilizer (15N) leaching in a central pivot fertigated coffee crop. Revista Ceres, Viçosa, v. 59, n. 4, p. 466-475, 2012.

BRUNO, I. P. et al. Fertilizer nitrogen in fertigated coffee crop: absorption changes in plant compartments over time. Field Crops Research, Amsterdam, v. 124, n. 3, p. 369-377, 2011.

Nitrogen balance and fertigation use efficiency in a field coffee crop. Journal of Plant Nutrition, Philadelphia, v. 38, n. 13, p. 2055-2076, 2015.

COELHO, G. et al. Efeito de épocas de irrigação e de parcelamento de adubação sobre a produtividade do cafeeiro 'Catuaí'.Ciência e Agrotecnologia,Lavras, v. 33, n. 1, p. 67-73, jan./fev. 2009.

CUSTÓDIO, A. A. de P.; GOMES, N. M.; LIMA, L. A. Efeito da irrigação sobre a classificação do café. Engenharia Agrícola, Jaboticabal, v. 27, n. 3, p. 391701, 2007.

FERNANDES, A. L. T. et al. Avaliação do uso de fertilizantes organominerais e químicos na fertirrigação do cafeeiro irrigado por gotejamento. Revista Brasileira de Engenharia Agrícola e Ambiental,Campina Grande, v. 11, n. 2, p. 159-166, 2007.

GUERRA, A. F. et al. Sistema de produção de café irrigado: um novo enfoque.Irrigação \& Tecnologia Moderna, Brasília, DF, v. 73, p. 52-61, 2007.

KARASAWA, S.; FARIA, M. A.; GUIMARÃES, R. J. Influência da irrigação e do parcelamento de fertirrigação sobre a produtividade, rendimento e qualidade do café (Coffea arabica L. cv. TOPÁZIO MG-1190). Ciência e Agrotecnologia,Lavras, p. 14271438, 2002. Edição especial.

LEITE JÚNIOR, M. C. R.; FARIA, M. A. Manejo da irrigação e da adubação do cafeeiro na sincronização do florescimento e na produtividade. Revista da Universidade Vale do Rio Verde, Três Corações, v. 14, n. 1, p. 505-518, 2016. 
LIMA, L. C. et al. Crescimento e produtividade do cafeeiro irrigado, em função de diferentes fontes de nitrogênio. Coffee Science, Lavras, v. 11, n. 1, p. 97 107, 2016.

MANTOVANI, E. C. et al. Irrigação: princípios e métodos. Viçosa, MG: Ed. UFV, 2009. 355 p.

MANTOVANI, E. C.; VICENTE, M. R. Manejo da Irrigação. In: SAKYIAMA, N. et al. (Ed.). Café arábica: do plantio à colheita. Viçosa, MG: Ed. UFV, 2015. p. 174-195.

NAZARENO, R. B. et al. Crescimento inicial do cafeeiro Rubi em resposta a doses de nitrogênio, fósforo e potássio e a regimes hídricos.Pesquisa Agropecuária Brasileira, Brasília, DF, v. 38, n. 8, p. 903-910, ago. 2003.

PEREIRA, L. S. et al. Crop evapotranspiration estimation with FAO56: past and future. Agricultural Water Management, Amsterdam, v. 147, p. 4-20, 2015.

RENA, A. B.; NACIF, A. P.; GUIMARÃES, P. T. G. Fenologia, produtividade análise econômica do cafeeiro em cultivos com diferentes densidades de plantio e doses de fertilizantes. In: ZAMBOLIM, L. (Ed.). Produção integrada de café. Viçosa, MG: Ed. UFV, 2003. p. 133-196.
REZENDE, R. et al. Initial growth of two coffee cultivars in different hydric regimes and fertigation dosages. Engenharia Agrícola, Jaboticabal, v. 30, n. 3, p. 447-458, 2010.

SANT'ANA, J. A. do V. Índice de área foliar, coeficiente de cultura e produtividade de cafeeiro fertirrigado. 2015. 144 f. Tese (Recursos Hídricos em Sistemas Agrícolas)-Universidade Federal de Lavras, Lavras, 2015.

SANTINATO, R. A nutrição em dobro do cafeeiro no Oeste da Bahia. In: ASSOCIAÇÃO DE AGRICULTORES E IRRIGANTES DO OESTE DA BAHIA. $5^{\circ}$ anuário de pesquisa da cafeicultura irrigada do oeste da Bahia. Barreiras, 2005. p. 50-54.

SOBREIRA, F. M. et al. Adubação nitrogenada e potássica de cafeeiro fertirrigado na fase de formação, em plantio adensado.Pesquisa Agropecuária Brasileira,Brasília, DF, v. 46, n. 1, p. 9-16, jan. 2011.

VENANCIO, L. P.; CUNHA, F. F.; MANTOVANI, E. C. Demanda hídrica do cafeeiro conilon irrigado por diferentes sistemas de irrigação. Revista Brasileira de Agricultura Irrigada, Fortaleza, v. 10, n. 4, p. 767$776,2016$.

VILELLA, W. M. da C.; FARIA, M. A. de. Crescimento do cafeeiro submetido a diferentes cinco lâminas de irrigação e três parcelamentos de adubação. Irriga, Botucatu, v. 8, n. 2, p. 168-177, 2003. 